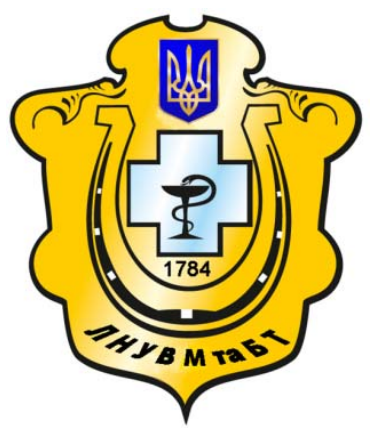

Науковий вісник Львівського національного університету ветеринарної медицини та біотехнологій імені С.3. Гжицького

Scientific Messenger of Lviv National University of Veterinary Medicine and Biotechnologies named after S.Z. Gzhytskyj

doi:10.15421/nvlvet7118

ISSN 2413-5550 print

ISSN 2518-1327 online

$\underline{\text { http://nvlvet.com.ua/ }}$

УДК 591.133.16: 612.52

\title{
Інтенсивність процесів ПОЛ у курчат-бройлерів за на тлі вакцинації проти хвороби Гамборо та за дії дріжджів Saccharomices cerevisiae і пробіотика БПС-44
}

\author{
М.М. Романович ${ }^{1}$, Б.М. Куртяк ${ }^{1}$, Н.А. Брода ${ }^{2}$, І.О. Матюха ${ }^{2}$ \\ kurtakbohdan@gmail.com \\ ${ }^{1}$ Львівський національний університет ветеринарної медицини та біотехнологій імені С.3. Гэницького, \\ вул. Пекарська, 50, м. Львів, 79010, Україна; \\ ${ }^{2}$ Інститут біології тварин НААН, \\ вул. В. Стуса, 38, м. Львів, 79034, Украӥна
}

\begin{abstract}
Стаття присвячена вивченню впливу згодовування курчатам-бройлерам у складі комбікорму препарату БПС-44 та різних доз дріжджів Saccharomyces cerevisiae на інтенсивність проиесів пероксидного окиснення ліпідів (ПОЛ) за умов їх вакиинаиії проти хвороби Гамборо.

Дослідження проведено на чотирьох групах курчат по 100 птахів у кожній. Контрольній групі курчат згодовували стандартний комбікорм (CK) та у 15-добовому вічฺі випоювали вакичину проти хвороби Гамборо (Gumbokal IM Forte SPF). Перша дослідна група птиџі додатково до СК отримувала - пробіотик БПС-44 (на основі штаму Bacillus subtilis 44) y кількості 0,21г/кг, друга дослідна група - 1\% дріжджів Saccharomyсеs cerevisiae. Третя дослідна група курчат - 2\% дріжджів Saccharomyces cerevisiae. Для досліджень використовували кров, яку брали в курчат після декапітації у різні вікові періоди: 11-, 27-, 34-і 41-добовому віиі.

Констатовано більший вміст проміжних і кінцевих продуктів ПОЛ в плазмі крові курчат-бройлерів у 27-, 34- $і$ 41добовому вічі порівняно до 11-добового, щчо свідчить про підвищення інтенсивності процесів ПОЛ $і$ вказує на їх залежність від віку та періоду імунізації птиці. Згодовування курчатам-бройлерам у складі комбікорму дріжджів Sассһаготусе cеrevisie та пробіотику БПС-44 спричиня інгібуючий вплив на інтенсивність процесів ПОЛ в їхньому організмі, а саме до зниження ( $p<0,01-0,001)$ вмісту гідроперекисів ліпідів і ТБК-активних продуктів, щчо може бути пов'язано з дезінтоксикаційними властивостями досліджуваних препаратів.

Ключові слова: кури-бройлери, кров, дріжджі, пробіотики, продукти перекисного окиснення ліпідів, хвороба Гамборо, система антиоксидантного захисту.
\end{abstract}

\section{Интенсивность процесса пол на фоне вакцинации болезни Гамборо и за действия дрожжей Saccharomices cerevisiae, пробиотиков БПС-44}

\author{
М.М. Романович ${ }^{1}$, Б.М. Куртяк ${ }^{1}$, Н.А. Брода ${ }^{2}$, И.А. Матюха ${ }^{2}$ \\ kurtakbohdan@gmail.com
}

\footnotetext{
${ }^{I}$ Львовский национальный университет ветеринарной медицины и биотехнологий имени С.3. Гжицкого, ул. Пекарская, 50, г. Львов, 79010, Украина;

${ }^{3}$ Институт биологии животных НААН, ул. В. Стуса, 38, г. Львов, 79034, Украина
}

\footnotetext{
Статья посвящена изучению влияния скармливания иььплят-бройлеров в составе комбикорма препарата БПС-44 и различных доз дрожжей Saccharomyсеs сеrevisiae на интенсивность процессов перекисного окисления липидов (ПОЛ) в условиях их вакиинации против болезни Гамборо.
}

\section{Citation:}

Romanovich, M.M., Kurtyak, B.M., Broda, O.N., Matyukha, I.A. (2016). Intensity of the floor on the background of vaccination Gumboro disease for the actions of yeast Saccharomices cerevisiae, probiotics BPS-44. Scientific Messenger LNUVMBT named after S.Z. Gzhytskyj, 18, 3(71), 79-82. 
Исследование проведено на четырех группах иыплят по 100 птии в каждой. Контрольной группе иыплят скармливали стандартный комбикорм (CK) и в 15-суточном возрасте випоювалы вакиину против болезни Гамборо (Gumbokal IM Forte SPF). Первая опытная группа птищы дополнительно к СК получала - пробиотик БПС-44 (на основе штамма Bасіllus subtilis 44) в количестве 0,21 г/кг, вторая исследовательская группа - 1\% дрожжей Saccharomyces cerevisiae. Tретья исследовательская группа иыплят - 2\% дрожжей Saccharomyces cerevisiae. Для исследований использовали кровь, которую брали у иыплят после декапитации в разные возрастные периоды: 11-, 27-, 34-и 41-суточном возрасте.

Констатировано большее содержание промежуточных и конечных продуктов ПОЛ в плазме крови иыплят-бройлеров в 27-, 34-и 41-суточном возрасте по сравнению с 11-суточного, что свидетельствует о повышении интенсивности проиессов ПОЛ и указывает на их зависимость от возраста и периода иммунизации птицы. Скармливания иыплят-бройлеров в составе комбикорма дрожжей Saccharomyces cerevisie и пробиотика БПС-44 вызывает ингибирующее влияние на интенсивность процессов ПОЛ в их организме, а именно к снижению $(p<0,01-0,001)$ содержания гидроперекисей липидов и ТБК-активных продуктов, может быть связано с дезинтоксикационными свойствами исследуемых препаратов.

Ключевые слова: куры-бройлеры, кровь, дрожжи, пробиотики, продукты перекисного окисления липидов, болезнь Гамборо, система антиоксидантной защчиты.

\title{
Intensity of the floor on the background of vaccination Gumboro disease for the actions of yeast Saccharomices cerevisiae, probiotics BPS-44
}

\author{
M.M. Romanovich, B.M. Kurtyak, O.N. Broda, I.A. Matyukha \\ kurtakbohdan@gmail.com \\ Lviv National University of Veterinary Medicine and Biotechnologies named after S.Z. Gzhytskyi, \\ Pekarska Str., 50, Lviv, 79010, Ukraine; \\ Institute of Animal Biology NAAS, \\ V. Stus Str., 38, Lviv, 79034, Ukraine
}

The paper studies the influence of feeding broiler chickens in the composition of animal feed preparation BPS-44 and various doses of the yeast Saccharomyces cerevisiae on the intensity of lipid peroxidation (LPO) in terms of vaccination against Gumboro disease.

The study was conducted on four groups of chickens at 100 birds each. The control group of chickens fed a standard feed (SC) and a 15-day-old vipoyuvaly vaccine against Gumboro disease (Gumbokal IM Forte SPF). The first experimental group of birds, in addition to the UK received - probiotic BPS-44 (based on Bacillus subtilis strain 44) in an amount of $0.21 \mathrm{~g} / \mathrm{kg}$, the second research group - 1\% of the yeast Saccharomyces cerevisiae. The third research group of chickens - 2\% of the yeast Saccharomyces cerevisiae. For studies using the blood that was taken from the chickens after decapitation at different ages: 11-, 27-, 34- and 41day-old.

It was stated a higher content of intermediate and final products of lipid peroxidation in the blood plasma of broilers in the 27-, 34- and 41-day-old, compared with 11-day, which indicates an increase in the intensity of lipid peroxidation processes and indicates their dependence on age and poultry immunization period. Feeding broiler chickens in the composition of feed yeast Saccharomuces cerevisie and probiotic BPS-44 causes an inhibitory effect on the intensity of lipid peroxidation processes in their body, namely a reduction ( $p<0,01-0,001)$ content of lipid hydroperoxide and TBA-active products can be detoxication properties associated with study drugs.

Key words: broilers, blood, yeast, probiotics, products of lipid peroxidation, Gumboro disease, antioxidant defense system.

\section{Вступ}

Підвищення збереження курчат у ранньому віці та забезпечення високої інтенсивності їх росту на всіх стадіях вирощування є однією з найбільш актуальних проблем сучасного птахівництва. Низька резистентність курчат у ранньому віці обумовлена їх біологічними особливостями, високою концентрацією поголів'я, негативним впливом технологічних факторів і недостатньо збалансованою годівлею (Kocjumbas et al., 2003; Akymenko, 2005).

Водночас відомо, що одним із факторів, які здатні викликати серйозні порушення росту і розвитку птиці на молекулярному рівні є активація вільнорадикальних процесів, передусім пероксидного окислення ліпідів (ПОЛ). Продукти ПОЛ є токсичними і накопичуються в організмі, що призводить до порушення функціонування організму вцілому, та різних систем і органів зокрема (Vlizlo et al., 2010). Пероксидне окиснення в організмі є фізіологічним процесом, але низка факторів (стрес, опромінення, дія токсичних речовин, критичні періоду онтогенезу, недостатньо збалансована годівля, інфекційні і вірусні захворювання тощо) викликають надмірну активацію інтенсивності ліпопероксидації з утворенням патологічно великої кількості агресивних та небезпечних активних форм кисню. Протидіє цим негативним процесам ендогенна антиоксидантна система, яка наявна у будь-якого живого організму і включає в себе низку ферментів та інших біологічно активних речовин, що запобігають інтенсифікації ПОЛ та подальшому накопиченню продуктів пероксидації. Це досягається шляхом знешкодження прооксидантів і вільних радикалів, а також детоксикації і виведення з організму токсичних продуктів пероксидного окиснення ліпідів (Danchuk, 2006). Доведено, що захворювання шлунковокишкового тракту птиці різної етіології супроводжуються активацією вільнорадикальних процесів в їх організмі, змінами у системі антиоксидантного захисту і порушеннями метаболізму білків, ліпідів, вуглеводів та енергетичного обміну (Ivanov, 2002). Введення до раціону сільськогосподарської птиці антиокси- 
дантів різної природи активізує захисні резерви організму та позитивно впливає на біохімічні процеси як у шлунково-кишковому тракті, так і в усьому організмі птиці (Kocjumbas et al., 2003). Одним із факторів активації ПОЛ можуть бути інфекційні захворювання.

Особливу небезпеку представляють захворювання, збудники яких проявляють тропізм до органів і клітин імунної системи, оскільки уражена птиця стає сприйнятливою i до інших захворювань. Одним із таких захворювань є хвороба Гамборо (хвороба фабрицієвої сумки, інфекційна бурсальна хвороба). Хвороба Гамборо уражує птицю сімейства куриних, характеризується діареєю, запаленням фабрицієвої сумки, імунодепресією. Найбільш сприйнятливі курчата у віці 215 тижнів і курчата віком менше як 3 тижні, які не мають материнських антитіл. На даний час остаточного лікування не розроблено, з метою профілактики використовують вакцинацію (Karysheva, 2002). Тому очевидним $\epsilon$ те, що пошук ефективних, безпечних $\mathrm{i}$ якісних способів профілактики та лікування захворювання є одним з пріорітетних завдань птахівництва та ветеринарної науки.

Дані літератури свідчать, що ефективним у цьому контексті є використання пробіотиків (Ivanov, 2002; Marteau et al., 2002; Kocjumbas et al., 2003; Akymenko, 2005) i, зокрема препарату БПС-44 (Agejev et al., 2006) та дріжджів Saccharomyces cerevisiae (Harms et al., 1987; Koval'chuk, 2006; Vlizlo et al., 2010; Kalyuzhin, 2011), що містять низку біологічно-активних речовин, які стимулюють процеси засвоєння поживних речовин корму завдяки нормалізації мікрофлори кишківника. Мікрофлора в свою чергу є джерелом адювантно -активних речовин, які проникають у кров, проявляючи стимулювальний вплив на імунну та антиоксидантну систему (Koval'chuk, 2006). Дріжджі Saccharomyces cerevisiae мають спеціалізовану систему, спрямовану на виведення 3 клітини як протонів, так і аніонів слабких органічних кислот. Окрім цього, дріжджі вважаються одним 3 найзручніших модельних об'єктів у дослідженні механізмів захисту клітини від оксидативного стресу. У літературі зустрічаються поодинокі повідомлення про те, що деякі штами мікроорганізмів із пробіотичними властивостями здатні підтримувати прооксидантно-антиоксидантний баланс в організмі сільськогосподарської птиці на фізіологічному рівні (Harms et al., 1987).

3 огляду на це мета роботи полягала у з'ясуванні впливу препарату БПС-44 та дріжджів Saccharomyces cerevisiae на інтенсивність процесів ПОЛ у курчатбройлерів на тлі вакцинації проти хвороби Гамборо.

\section{Матеріал і методи досліджень}

Дослідження проводили у фермерському господарстві Золочівського району Львівської області на чотирьох групах курчат-бройлерах по 100 голів у кожній, починаючи 3 1- до 45-добового віку. Утримання курчат було клітковим 3 вільним доступом до корму і води. Контрольній групі курчат згодовували стандартний комбікорм (CK), збалансований за основними поживними речовинами згідно норм, рекомендованих для кросу РОСС - 308 та у 15-добовому віці випоювали вакцину проти хвороби Гамборо (Gumbokal IM Forte SPF). Курчатам першої дослідної групи аналогічно згодовували СК із додаванням пробіотика БПС-44 (на основі штаму Bacillus subtilis 44) у кількості 0,21г/кг Другій дослідній групі птиці - із додаванням 1\% дріжджів Saccharomyces cerevisiae, птиці третьої дослідної групи - із додаванням 2\% дріжджів Saccharomyces cerevisiae. Для досліджень використовували кров, яку брали в курчат після декапітації у різні вікові періоди: 11-, 27-, 34- і 41-добовому віці. Під час виконання роботи дотримувались біоетичних вимог, щодо тварин згідно чинного законодавства. Результати досліджень різних вікових груп курчатбройлерів порівнювали із величинами показників птиці 11-добового віку після вакцинації і до контрольної групи птиці.

У плазмі крові визначали вміст гідроперикисів ліпідів (ГПЛ; Мирончик А. К., 1982) і ТБК-активні продукти (Коробейникова Е. Н., 1989).

Одержані цифрові дані опрацьовано статистично 3 використанням програмного пакету Microsoft Excel для персональних комп'ютерів, за допомогою загальноприйнятих методів варіаційної статистики $з$ визначенням середніх величин (M), їх квадратичної похибки (m) та достовірності

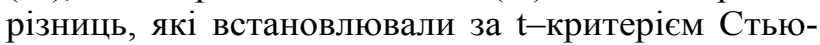
дента.

\section{Результати та їх обговорення}

Як зазначалося пероксидне окиснення ліпідів є фізіологічним процесом. У мембранах мітохондрій підтримується стаціонарний рівень ПОЛ, що має певне функціональне значення і відображає ступінь впливу молекулярного кисню на мітохондріальні ліпіди в нормальних фізіологічних умовах. При цьому, роль пероксидних процесів визначається їх здатністю регулювати структурно-функціональний стан мембран, що має вирішальне значення для функціонування ферментних систем (Kalyuzhin, 2011).

Проведені дослідження показали, що вміст проміжних і кінцевих продуктів ПОЛ у плазмі крові курчат-бройлерів контрольної групи у 27-, 34- і 41добовому віці був більший, ніж у 11-добовому віці (табл.). При цьому різниці були вірогідними за вмістом гідроперекисів ліпідів ( $<0,001)$. Ці дані свідчать про зростання інтенсивності процесів ПОЛ в організмі птиці з віком та проведеною імунізацією. Необхідно зауважити, що найбільш інтенсивне зростання процесів ПОЛ зафіксовано у крові курчат у період активного росту.

Згодовування курчатам дослідних груп у складі комбікорму препарату БПС-44 та дріжджів Saccharomyces cerevisiae спричиняло зниження вмісту проміжних і кінцевих продуктів ПОЛ у плазмі крові. Так, у курчат дослідних груп у 27-, 34- і 41-добовому віці вміст гідроперекисів ліпідів та ТБК-активних продуктів у плазмі крові був менший ( $<<0,01-$ 0,001), ніж у контролі. Ці дані свідчать про інгібуючий вплив досліджуваних чинників на вміст проміжних і кінцевих продуктів ПОЛ, рівень яких значною мірою регулюється ферментативною та неферментативною ланками системи антиоксидантного захисту. 
Антиоксидантна система захищає клітини і організм в цілому від токсичної дії радикалів Оксигену та пероксидів ліпідів, а також знешкоджує токсичні продукти, що проявляють мембранодеструктивну дію. Порушення проокисно-антиоксидантного балансу призводить до оксидативного стресу, що характеризується значним прискоренням процесів ПОЛ, накопиченням вільних радикалів на тлі зниженої активності системи антиоксидантного захисту (Kalyuzhin, 2011), що особливо $\epsilon$ актуальним в організмі птиці в умовах стресу та вакцинації.

Вміст продуктів пероксидного окиснення ліпідів у плазмі крові курчат-бройлерів (M \pm m; $\boldsymbol{n}=5)$

\begin{tabular}{|c|c|c|c|c|c|}
\hline \multirow{2}{*}{ Показники } & Групи & \multicolumn{4}{|c|}{ Вік курчат-бройлерів, доба } \\
\cline { 2 - 6 } & & 11 & 27 & 34 & 41 \\
\hline \multirow{3}{*}{$\begin{array}{c}\text { МдА, } \\
\text { мкмоль/мл }\end{array}$} & $\mathrm{K}$ & $1,72 \pm 0,013$ & $1,84 \pm 0,025$ & $2,01 \pm 0,013$ & $2,28 \pm 0,090$ \\
\cline { 2 - 6 } & $Д_{1}$ & $1,66 \pm 0,034$ & $1,58 \pm 0,049^{* * *}$ & $1,68 \pm 0,039^{* * *}$ & $2,05 \pm 0,066$ \\
\cline { 2 - 6 } & $Д_{2}$ & $1,74 \pm 0,060$ & $1,64 \pm 0,048^{* * *}$ & $1,63 \pm 0,031^{* * *}$ & $1,75 \pm 0,029^{* * *}$ \\
\cline { 2 - 6 } & $Д_{3}$ & $1,67 \pm 0,037$ & $1,61 \pm 0,031^{* * *}$ & $1,55 \pm 0,036^{* * *}$ & $1,57 \pm 0,041^{* * *}$ \\
\hline \multirow{3}{*}{$\begin{array}{c}\text { ГПЛ, од. } \\
\text { Е/мЛ }\end{array}$} & $\mathrm{K}_{1}$ & $0,34 \pm 0,01$ & $0,41 \pm 0,007^{\text {о0о }}$ & $0,42 \pm 0,007^{\text {000 }}$ & $0,46 \pm 0,008^{\text {о00 }}$ \\
\cline { 2 - 6 } & $Д_{1}$ & $0,33 \pm 0,005$ & $0,34 \pm 0,006^{* * *}$ & $0,37 \pm 0,005^{* * *}$ & $0,43 \pm 0,005^{* *}$ \\
\cline { 2 - 6 } & $Д_{2}$ & $0,31 \pm 0,005$ & $0,33 \pm 0,008^{* * *}$ & $0,36 \pm 0,006^{* * *}$ & $0,40 \pm 0,005^{* * *}$ \\
\cline { 2 - 6 } & $Д_{3}$ & $0,33 \pm 0,017$ & $0,33 \pm 0,007^{* * *}$ & $0,35 \pm 0,005^{* * *}$ & $0,37 \pm 0,005^{* * *}$ \\
\hline
\end{tabular}

Примітка. У цій таблиці різниці статистично вірогідні порівняно з контролем: * $-\mathrm{p}<0,05 ; * *-\mathrm{p}<0,01$; ** $-\mathrm{p}<0,001$; вірогідність різниць до періоду вакцинації. ${ }^{\circ}-\mathrm{p}<0,05 ;{ }^{\circ 0}-\mathrm{p}<0,01$; ${ }^{\text {ooo }}-\mathrm{p}<0,001$

Отже, на основі проведених досліджень можна констатувати, що згодовування курчатам дослідних груп у складі комбікорму препарату БПС-44 та дріжджів Saccharomyces cerevisiae дозволяє запобігти несприятливому впливу на курчат-бройлерів таких факторів, як критичні періоди росту та імуносупресію, що досягається за рахунок підвищення адаптогенних можливостей організму шляхом модулюючого впливу пробіотиків на стан антиоксидантної системи птахів.

\section{Висновки}

Встановлено, що вміст гідроперекисів ліпідів у плазмі крові курчат-бройлерів у 27-, 34- і 41добовому віці був більший $(\mathrm{p}<0,001)$, ніж у $11-$ добовому віці. Згодовування курчатам-бройлерам у складі комбікорму дріжджів Saccharomyces cerevisie та пробіотику БПС-44 спричиняє інгібуючий вплив на інтенсивність процесів ПОЛ в їхньому організмі, а саме до зниження $(\mathrm{p}<0,01-0,001)$ вмісту гідроперекисів ліпідів і ТБК-активних продуктів, що може бути пов'язано $з$ дезінтоксикаційними властивостями досліджуваних препаратів.

\section{Бібліографічні посилання}

Akymenko, L. (2005). Probiotyky u veterynarnij medycyni. Veterynarna medycyna Ukrai'ny. 5, 37-38 (in Ukrainian).

Vlizlo, V.V., Koval'chuk, Ja.Ja., Vishhur, O.I., Koval'chuk, I.I. (2010). Pokaznyky krovi ta intensyvnist' rostu porosjat pry dii' drizhdzhiv Saccharomyces cerevisiae. Nacional'nogo universytetu bioresursiv i pryrodokorystuvannja Ukrai'ny. 151(1), 49-53 (in Ukrainian).

Danchuk, V.V. (2006). Peroksydne okysnennja u sil's'kogospodars'kyh tvaryn i ptyci. Kam'janec'-
Podil's'kyj: Abetka (in Ukrainian).

Ivanov, I.V. (2002). Uvelichenie proizvodstva i kachestva produkcii $\mathrm{s}$ primeneniem probiotikov. Vysokojeffektivnye biotehnologii $\mathrm{V}$ proizvodstve jekologicheski bezopasnyh produktov pitanija i biopreparatov dlja naselenija. Novosibirsk, 63-65 (in Russian).

Kocjumbas, I.Ja., Rozhko, M.S., Kushnir, I.M. (2003). Zastosuvannja probiotykiv u veterynarnij medycyni // Veterynarna medycyna Ukrai'ny. 10, 15-17 (in Ukrainian).

Karysheva, A.F. (2002). Special'na epizootologija: Pidruchnyk. K.: Vyshha osvita (in Ukrainian).

Agejev, V.O., Smol's'kyj, O.S., Smol's'ka, T.M., Derev'janko, S.V., Bozhok, L.V. (2006). Vplyv probiotyka BPS-44 na stan antyoksydantnoi' systemy organizmu koropa. Sil's'kogospodars'ka mikrobiologija: Mizhvid. temat. nauk. zb. 3, 93-103 (in Ukrainian).

Koval'chuk, Ja.Ja. (2006). Vplyv zgodovuvannja biomasy drizhdzhiv Saccharomices cerevisiae na antyoksydantnyj status porosjat-sysuniv. Naukovotehnichnyj bjuleten' Instytutu biologii' tvaryn NAAN ta DNDKI vetpreparativ ta kormovyh dobavok. 7(12), 186-188 (in Ukrainian).

Harms, N.K., Bertele-Harms, R.M., Bruer-Kleis, D. (1987). Enzyme substitution therapy with the yeast Saccharomices cerevisie in congenital sucroseisomaltase deficiency. N. Engl.J. 316, 1306-1309.

Kalyuzhin, V.A. (2011). Thermoresistance in a yeast Saccharomyces cerevisiae. Zhurnal Obshchei Biologii 72(2), 140-149.

Marteau, P., Seksik, P., Jian, R. (2002). Probiotics and intestinal health effects: a clinical perspective. Br. J. Nutr. 88(1), 51-57.

Стаття надійшла до редакиії 5.09.2016 